\title{
PARADIGM SHIFT IN IRAQI WOMEN WRITING WITH SPECIAL REFERENCE TO BETOOL KHEDARI'S A SKY SO CLOSE AND LEILAH NADIR'S THE ORANGE TREES OF BAGHDAD
}

\author{
Ahmed Saad AZIZ \\ University of Al-Qadisiyah, Iraq
}

(C) The Author(s) 2018

\begin{abstract}
Essentially, feminism signifies women starting to rise in all those fields which were earlier considered as male preserves. The growth of women in the professional world led to their emancipation further leading to the progress of their respective countries. The freedom which these women had acquired by expressing themselves through writing had motivated even common women to stand up for their rights, equality and liberty worldwide. There was a time when Marie Anne Evans had to take up a pseudonym 'George Eliot' for expressing her feelings and experience in the form of writing. She had to take up a 'male pen name' to establish herself and be taken in the world of writing which for entirely maleoriented. But in the contemporary scenario, we see women writers even from the lowest structure of society or even from the most conservative societies who are raising their voices and are inspiring millions and millions of women worldwide.

This paper discuses paradigm shift in Iraqi women writing with special reference to Betool Khedari's novel, A Sky So Close and Leilah Nadir's memoir's The Orange Trees of Baghdad
\end{abstract}

C2018.All rights reserved

\section{ARTICLE HISTORY}

Received: 23/11/2017

Accepted: $16 / 03 / 2018$

Published online: 01/04/2018

\section{KEYWORDS}

Iraqi women writing, feminism,

emancipation, displacement, conflict

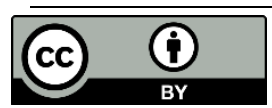

www.ijhsdr.com 


\section{Introduction}

The rise of the feminist movement has not only influenced the women of the Western world but it has its impact on Asian countries as well. It may have come a little later in Asia than Europe but the effect has been tremendous signifying the emergence and rise of women in all fields of human activity previously dominated by males, as the noted critic and Emeritus Professor Jasbir Jain rightly points out :

Feminism, which gained momentum in the 1960s and 1970s, tried to raise women's consciousness against their victimization. It can be considered a reaction of women to life, their status at home and in a society that has shaped and defined the lives of men and women all over the world. (19)

Iraq as a part of the Arab world is not separated from this worldwide development - indeed it is the country which has seen the dramatic appearance of women writers, famous not only in their homeland but around the world, in recent years though being in conflict from a long time. Originally, Iraqi women writers focused on the same themes and pattern of writing as men writers but with the passage of time they shifted their attitude - from the earlier didactic style to social and moral values, a strong sense of social and national consciousness with fictional characters reflecting the politics of their times, entirely different from male writers.

Unable to resist the influences of the changes on the women's global writing scene, they adopted a different approach in attempting to solve the crisis existing in their society, expressing views very diverse from those men were writing about, such as Arab nationalism, Communism and Islam. In 1937, Dalal Khalil Safadi published Hawadith Waibar (Incidents and Lessons), a collections of short stories which caused a sensation among women writers in Arabia, including those new writers emerging on the Arab literary scene. It paved the way for writers like Safira Jamil Hafiz to publish a collection of short stories in 1956 named Dumma wa atfal (Dolls and 
Children) which was quite popular. Although Doreen Ingrams has criticised her writing by describing Safira Jamil Hafiz as a "left-wing activist who was more concerned with her political cause than with their art of fiction," this demonstrates how strongly political happenings affect a writer, with the influences becoming easily visible in his/her writings. This is the growth of gynofiction worldwide as Jasbir Jain clarifies:

The emergence of gynofiction in the twentieth century as a powerful subgenre of fiction is a global phenomenon. Since women writers have been recording their experiences and since each experience is unique in itself, based as it is in a particular cultural, social, political and religious milieu, this fiction serve as an authentic mirror to the socio-cultural reality of the time. It acquires a special significance through the exploration of new dimensions of reality, the changing role and status of women, and the recognition of the bond of sisterhood. (14)

This led to the changing in themes and perspective of women writers in their writings. Many writers in Iraq substantially shifted their focus and themes from the earlier writing in the 1950s and 1960s voicing their views on a myriad themes relating to women. Examples might be contemporary issues, women's emancipation, the struggle and survival against the various injustices inflicted on them, the rise of many crimes against women in society. They strive to highlight facets of belonging to a country which has been a victim of war and Western interventions resulting in the devastation of Iraq and its dangerous impact of people especially women, showing their concern to change the conditions in Iraq.

This not only led the growth of women's literature but also women's emancipation, exemplified by their also boldly facing issues like extramarital affairs through focusing on marital relationships as themes. However, the current focus of women writers is primarily on the consequences of war and its aftermath on Iraqi people worldwide particularly women. 
From among the many women writers in Iraq, my intention in this paper is to focus on three writers, Betool Khedairi and Leilah Nadir.

Betool Khedairi is an Iraqi novelist, born on $27^{\text {th }}$ November 1965 in Baghdad, Iraq to an Iraqi father and Scottish mother. Her debut novel, A Sky So Close, which was first published in Lebanon in 1999, became very popular and she earned name and fame the world over, with her work being translated into a number of languages from the Arabic including into English by Muhayman Jamil, Italian, French and Dutch. The novel has been used as the subject of literary critique studies in various universities around the world. Her second novel Absent has also been translated from the original Arabic into English by Muhayman Jamil.

A Sky So Close is a lyrical novel telling the story of a young woman coming of age in modern Iraq. The narrator of the story is an unnamed girl, who had lived in a small village of Zafraniya, outside Baghdad in the 70s and 80s and had suffered the isolation of an individual who is being caught in the conflict of clash of cultures as her father belongs to Iraq and mother from Europe. Her mother who belonged to another land but due to certain circumstances is living in a place which is quite alien to his/her own culture. Her father being a traditional though have gained education west but had the oriental mind-sets. The husband and wife were never on agreement on any issue though it was their love marriage but they always quarrel on smallsmall things make things miserable for their daughter. But being a child, she was not aware of the seriousness of this issue. She recalls her early childhood, a time of peace in Iraq, spent on the farm in her village. Like other children she attended a school of Music and Ballet in the mornings. The afternoons were her time to play among the apricot trees. She has described about the landscape of her village's landscape with a poetic imagination reflecting her sensitivity towards her native land, as she says:

Zafraniya, it was called "Land of Saffrons." That was where the apricot tree grew. Vast acres of graceful trees, their upper branches entwined. When the sun starts to sink over the apricot farm, their shadows fall as complex patterns of light and shade on the ground underneath. The 
youthful branches stretch out in all directions. Their sharp twigs seem like fingers, entangled in handshakes, exchanging bunches of white flowers. (6)

The above description of landscape of a small Iraqi village through a fictional character reflects Khedeiri nostalgia and her deep love towards Iraq. Although the landscape was beautiful but it didn't provided tranquillity in her life as being the daughter of an Iraqi father and an English mother, she had to face the conflicting cultural values of East and West from her childhood. This had an adverse impact, disrupting the peace in her life.

Her parents argued continually because of differences of opinion and culture. Her mother was not able to adapt to the new surroundings in Iraq as it was alien to her, and in the neighbourhood the little girl was considered "the foreign woman's daughter." Living in such discord, she became closer to her father, who was an inspiring figure for her as she grew into adolescence. After some time the family moved to Baghdad but in the same year the Iran- Iraq war broke out in 1980, affecting the daily lives of the citizens of the country, as well as her own. They had to undergo many changes due to the war: travel restrictions, closure of the dance schools and many more such things. Being born and lived in Iraq in those turbulent times, Khedairi herself is a witness of all these experiences which she has moulded in the form of novel. Though she has described the political condition in her novel but she claims to be not interested in politics which seems ironical.

Amidst all this chaos, the narrator got the chance to meet a beleaguered artistic community in Baghdad and she experienced her first love affair. Her lover was a middle-aged middle man, a Christian by faith who often come and goes in her life leaving a vacuum in a young girl's life. As being an army man and living in a time when Iraq is constantly in war, he has to give his services to his nation. He loves her deeply but did not bind her in his love so when her father dies, he sets her free and advises her to take her mother and go to England as her life and future in unsafe in her native place. 
As he tells her in his letter, "Cross to the other side. Travel far away. Roam the lands. Seek ... maybe you'll find a just settlement with the soul." (183)

In the last part of the novel, when the narrator's father dies, the focus shifts from Baghdad to England. She travels with her ailing widowed mother, suffering from cancer, for medical treatment, at the beginning of the Gulf War in 1990. It is also the time when her relationship with her lover comes to an end when he goes to fight for the country. She loved her motherland, Iraq, and although she loved her lover a great deal, she sacrificed her desire out of her sense of responsibility towards her mother.

When she goes to England, in the beginning she finds herself alien to the new surrounding as she was born in the Oriental Muslim world. This feeling of alienation arises in her because born and brought up in a traditional world, she felt unaccepted. Although she has grown up between two cultures but in her own country Iraq and here in England, emptiness engulfed her day and night. This emptiness was passed to her by her mother who has lived in a "strange culture and language, and the unbearable heat" (200). This sense of unbelonging in the novel has been stemmed from Kheidari's own experiences in life. She and her family had to leave their motherland due to political instability and seek refuge in other country. Living in another country has never given her the sense of belonging which she finds in her country. This sensitivity had later taken the shape of novel where she has poured down her emotions. As her character speaks:

It is a foolish notion, this question of belonging. We only belong to the shadows of our bodies which follows us around as long as we're alive. (201)

This is the fate of millions of people like the author herself who due to conflict had to leave their country and live a life of migrant or refugee in a land which is alien to them. There are examples of Palestinians, Afghanistan and Syrians.

If we see the story of $A$ Sky So Close, we find a peculiarity which is that the novelist did not use the name of the narrator. She is called, "the girl" by her 
parents, her first lover in Iraq calls her, "little one" and her dance teacher calls her, "my friend." This is the reflection of the alienation and dissonance which Khedairi wants to depict through the character of the narrator, making the experience timeless and universal. She has also highlighted the ill effects of cross-cultural marriage leading to frequent conflicts and arguments between husband and wife, resulting in a life of discord for their children. Khedairi has created poetic descriptions in the novel though writing with a certain distance and passivity. The novel is a coming of age story of an Iraqi childhood, unusual but beautifully written. It is considered an elegy to her dead parents. It deals with many themes such as the cross-cultural issue, and the effects of war on common people including economic sanctions leading to their miseries, and her own isolation.

The novelist depicts the invasion of Iraq by the West and life in such a war-torn country in a very emotional way, moving to Baghdad and then to England, describing the warm relationship between the narrator and her father. The female protagonist of the novel is a strong woman who deals with the complex relationship of her parents who belong to two cultures: East and West. The novel is very touching and engaging, giving readers an inside look of a war- torn country, the loss of innocent lives and the destruction war wreaks on people. As the Pakistani writer, Kamila Shamsie in her novel, Burnt Shadows describes it: War is like disease. Until you've had it, you don't know it. But no.That's a bad companion. At least with disease everyone think it might happen to them one day. You have a pain here, swelling there, a cold which stays and stays. You start to think maybe this is something really bad. But war- countries like yours (US) they always fight wars, but always somewhere else. This is why you fight more wars than anyone else. The disease always happen somewhere else. It's why you fight more wars than anyone else; because you understand war least of all. You need to understand it better. (344)

Through this novel, Khedairi has tried to attract the world attention towards Iraq, a country facing political instability due to lack of policies on one hand and being a victim of Western imperialism on the other land. As Brigitte Voykowitsch, a reviewer believes that the novel is about Iraq. Author had 
told the story about the freedom and imagination of an Iraqi child caught up in a complex struggle because she belongs to two different identities, cultures and traditions. So it is about racism at the same time the shadows which war cast on societies even long after they are finished because though war in Iraq has ended long back but it has its impact till now and even in future it will continue to affect people socially, politically, psychologically and physically. Khedairi has told this story of a young Iraqi girl growing up in such an atmosphere in a simple and unpretentious way. Through this novel, she has offered a fresh look on children growing up in the villages of Iraq in the 1970s when there was no war. This is a commendable effort of her. Another women writer from Iraq, Leilah Nadir is also an Iraqi born novelist and writer living in Vancouver, British Columbia, Canada with her husband and a son, the daughter of an ethnic Assyrian Iraqi Christian and an English lady. Brought up in Britain and Canada, she has a Master's degree in English Literature from the University of Edinburgh and holds a Joint Honours Bachelor's degree in subjects; English and History from McGill University.

She has worked in the publishing industry in both London and Vancouver but after the US-led invasion of Iraq in 1990, she wrote many articles on the issue elaborating her views. One of her articles was featured in the prestigious Brick magazine. She has also broadcast political commentaries for various channels like $\mathrm{CBC}$, The Globe and the Mail and The Georgia Straight. Her works include: The Orange Trees of Baghdad: In Search of My Lost Family, Heavenly Bodies, Bazaar, Still. She also writes fiction and has a play to her credit, Heavenly Bodies. In 2008, she published The Orange Trees of Baghdad: In Search of My Lost Family, which is a memoir on Iraq, giving details of her father's story and the experiences of her family in the country since the US-led invasion in 2003. It was published in Italy, Australia and New Zealand in 2008 and in France in September in 2009. It is a pictorial book containing pictures of her family as well as contemporary photos by the famous Iraqi Canadian photojournalist, Farah Nosh. It became very popular and was widely praised around the world for its visual quality depicting the experiences and sufferings of people upon whom war is forcefully imposed. Naomi Klein, the author and social activist, is among 
those who have highly praised the book, and Nadir won the George Ryga award for Social Awareness in Literature in July 2008. She comments as:

Leilah Nadir's The Orange Trees of Baghdad reminds us that Iraq is not just a war; it is a country. Lovingly woven together from inherited memory and family lore, her Iraq is infinitely more vivid, more textured, and more heartbreaking than what we see nightly on the news. In the debates about winning and losing the war, this is a book about what loss really means - the theft of history and of homeland. (2) Such is her description which has made people realized that Iraq has suffered a lot and it is a country which has a glorious past. A country, which is labelled with a common epithet as "Cradle of Civilization" because much of the world's earliest writing began here with a rich history of literature, sciences, mathematics, law and philosophies.

The Orange Trees of Baghdad: In Search of My Lost Family begins with an introduction where Nadir is describing about her garden in Baghdad, which is not her recollection since she has never lived there but it is a picture hidden inside her father's memory. She compares it with mythical stories since mostly mythical stories begin with garden. Although she has not lived in Iraq but has a deep love for it and she feels that Iraq is her bones. Her father Ibrahim had left Iraq when he was sixteen years old in 1960 to gain education in England. Since then he has never visited Iraq though he desperately want to. This is the fate of millions of other Iraqis as Nadir describes:

Around the world, there are approximately five million exiles from a country of twenty-five million; about one in five Iraqis does not live in Iraq. Most of them, like my father, are afraid to go back, even in peace time. So we never have. (16) So, due to political instability and conflict her father didn't go there but the memories of his homeland were always fresh in his mind and he has passed on this to his next generation.

Nadir too like the protagonist of Khedairi's novel, A Sky So Close has parents belonging to two opposite cultures; East and West. Her mother is from Britain and her father from Iraq but the situation is different as here as 
they have lived in West; in Canada and England unlike the story of Khedairi's novel. So there is no discord between her parents and hence she has not experience the East/West conflict in her own home like the unnamed protagonist of A Sky So Close.

Throughout the book, she has depicted various issues and problems which people face when they are caught up in the war. She gives the instances and consequences of American imperial war on Iraq unlike Khedairi who has depicted Iran-Iraq in her novel. American regime had imposed war on Iraq giving excuse that Saddam Hussein had weapons of mass destruction which was all lies just to target Saddam regime and their greed for oil. As Nadir aunt had told her, "The country has nothing, no medicine, no food, no money, never mind weapons! How can people believe this?" (28). This American war is basically modern imperialism leading to collateral damage. Later on she tells her: "These two wars, the Gulf War and this one, are were much worse for Baghdad than the Iran Iraq War," Amal says bitterly. "They never bombarded Baghdad every single day in the Iran one or two weeks." (95)

\section{Iraq War. Only once every}

This is the description of destruction of Baghdad due to the air-strikes by the American forces which Nadir has described in her book. Though she has not lived in Iraq but Nadir feel deeply connected with it as her roots are in Iraq and seeing the destruction of her native land she feels as if she has been robbed.

Both the writers had emphasized on the various problems and issues that arise due to conflict in one's own country; the most important is the displacement of people from one country to country. This displacement results in social and cultural differences as well as psychological traumas which one undergoes due to change of place. And although a person changes his/her but is not able to forget one's native place whose memories always haunts and it is difficult for them to make their home in the new found land. 
The famous Indian diasporic poet, Meena Alexander has expressed her concern in one of her poem: "I am a woman cracked by multiple migrations. Uprooted so many times she can connect nothing and nothing". (Alexander, 1993,3). These words reflect her agony of being a migrant who has travelled many places and for whom travelling has become a form of increasing alienation and marginalization. This echoes in the writings of Khedairi and Nadir as both have talked about belonging and un-belonging in their novel and memoir. Leaving their native lands due to conflict and moving to other lands has not given them the sense of being at "home" rather it has created a sense of alienation in them. Though living for many years in their new found homes, they are not able to forget their motherland and wish to go back. As writer, Lisa Majaj reminds herself and others about her identity and her connectivity towards the land which she has left behind in one of her poem entitled 'Claims': "I am the wheat stalk, and I am the olive. I am plowed fields young with the music of crickets; I am ancient earth struggling to bear history's fruit" (Kadi, 1994,84). This sense of loss and displacement can be seen in almost all diasporic writers which has stemmed in them because of the rejection which they have experienced in their new land and the nostalgia pertaining their original homelands.

These two Iraqi women: Betool Khedairi and Leilah Nadir have depicted the sufferings of displaced people due to war in general and women in particular in their writings. They are not only representative writers of their country but also messengers of peace who have experienced many problems created due to the political turmoil in their country and its aftermath. They are the role models who not only serve as a base for the women of their country but women around the world in general. They belong to a country which has been devastated by invasion and war but along with others they are trying to mend the damage done through writing and other activities. They have survived against all odds and in adverse situations with flying colours and are now telling their experiences through their books.

In my paper, I have tried to justify the efforts they make raising their voices against the patriarchal society as well as highlighting the experiences of women affected by the worst violence anywhere in the world. Their voice is 
the voice of "new women" who do not consider themselves marginalised and subordinate but fight against any injustice or subjugation imposed upon them. They are strong individuals who possess all those qualities which make them equivalent to men and this is quite apparent in their writings.

\section{Disclosure statement}

No potential conflict of interest was reported by the author.

\section{Contact Information}

E-mail: ahmedaziz.eflu@gmail.com 


\section{References and notes:}

Jain, Jasbir edited Women's Writing: Text \& Context Rawat Publications: New Delhi, 2014. Third Edition.

Khedairi, Betool (2003)A Sky So Close. New York: Penguin Random House.

Cooke, M. (1987). War's Other Voices Women Writers on the Lebanese Civil War. Cambridge: Cambridge University Press.

Shamsie, Kamila Burnt Shadows.2009. Bloomsbury Publishing: London https://middleeastrevised.com/2014/12/30/the-book-to-read-a-sky-soclose-by-betool-khedairi/

Nadir, Leilah. 2007.The Orange Trees of Baghdad: In Search of My Lost Family. Red Leaf: USA, 2007.

Alexander, M. Fault Lines: A Memoir. Feminist Press: New York, 1993.

Kadi, Joanna ed. 1994.Food of our Grandmothers: Writings by Arab-American and ArabCanadian Feminists

http://www.leilahnadir.com/LeilahNadir_book.html

http://www.cscanada.net/index.php/sll/article/view/5959/7000

http://dx.doi.org/10.7575/aiac.ijalel.v.3n.1p.124 